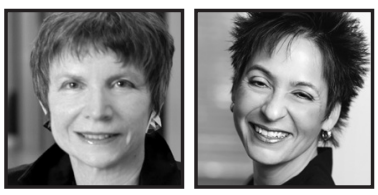

\title{
Musical Leadership and Societal Transformation: Inspiration and Courage in Action ${ }^{1}$
}

\author{
Nancy J. Adler, McGill University \\ Linda M. Ippolito, York University
}

\begin{abstract}
Music is a form of leadership. Music-based interventions in organizations and society are being used throughout the world, including in situations of extreme conflict and consequence. Artists are going beyond the dehydrated language of economics, politics, and war to achieve goals that have eluded those using more traditional approaches. This article presents musical interventions in Bosnia-Herzegovina, Cyprus, Estonia, Northern Ireland, the Middle East, South Africa, the United States, and Venezuela, in which musicians have had the inspiration and courage to make a difference.
\end{abstract}

The radical shift in the structure of the world begs for creativity; it asks us to rethink who we are as human beings... It may be that writers, painters, and musicians have an unprecedented opportunity to be co-creators with society's leaders in setting a path. For art, after all, is about rearranging us, creating surprising juxtapositions, emotional openings, startling presences, flight paths to the eternal.

— Rosamund and Benjamin Zander (1998, p. 7) ${ }^{2}$

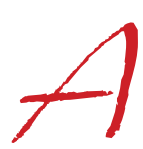

rt transforms apathy into action. ${ }^{3}$ Social scientist Ken Gergen (1999) invites us all to become "poetic activists" (p. 12). Perhaps there is no better label for the use of musical interventions in global and organizational crises than that of poetic activism. Activists, great artists, and great leaders share three fundamental perspectives (Adler, 2006, 2010, 2011, 2015). They all demonstrate the courage to see reality the way it is. They all exhibit the courage to imagine possibility-positive 
futures - even when the world labels such imagination as naïve for daring to express optimism. And they all have the courage to inspire people to move from current reality back to possibility.

Over the past half-century, with no singular organized movement or unifying philosophy to guide them, artists and artistic processes have attempted to transform reality in numerous contentious situations. In particular, music has been used to address extreme conflict and the threat of conflict, along with the dysfunction and degradation that conflict so often causes (see Tongeren, 1999; Urbain, 2008; Ippolito, 2008). ${ }^{4}$ Music, most often when combined with other approaches, appears to have produced generative outcomes in some, although not all, situations in which it has been introduced. In many circumstances, musical interventions have inspired the broader community (see Tongeren, 1999; Welch \& LeBaron, 2006; Ippolito, 2008; Cohen, Gutiérrez Varea, \& Walker, 2011). Such initiatives exemplify the frame-breaking perspectives and approaches that music has the potential to offer.

\section{Poetic Activism: Going Beyond the Dehydrated Approaches of Economics, Politics, and War}

Transforming ourselves, our relationships, or our culture need not await the intervention of some expert, a set of laws, public policies or the like.... [We all] participate in creating the future for good or ill. If we long for change, we must ... confront the challenge of generating new meanings, of becoming poetic activists. - Kenneth Gergen (1999, p. 12)

Musicians and musical ensembles have a history of poetic activism-of acting as leaders by revealing the truth of reality and giving shape, form, and sound to "the possible." The act of creating music and the music itself inspire people to go beyond ugly, dysfunctional, and all too often brutal reality to create possibility, thus offering the beauty inherent in newly found opportunity. Musicians and ensembles do not rely simply on intellectual constructs and commitments, but rather powerfully influence situations through emotions and strong subconscious dynamics (see McNeill, 1997; Freeman, 2000; Benzon, 2001).

Musical interventions have not been universally successful, no matter how broadly success is defined (Bergh, 2010, 2011; Bergh \& Sloboda, 2010). What is universal, especially today, is aspiration: the aspiration to do better than we have done previously; 
to return to the best of what humanity is capable of; to move from ugliness back to beauty (Adler, 2011, 2015). This article highlights collaborative musical interventions among both like-minded people and adversaries. Among the former, music inspires, motivates, supports, and encourages people in their quest to collectively achieve goals of great consequence-such as political independence, democracy, poverty reduction, and the rehabilitation of criminals - that are of the utmost importance to them and their society. Among the latter, musical initiatives bring foes together to heal the seemingly insurmountable divisiveness that prolonged conflict produces. The selected examples are not meant to be exhaustive, but rather illustrative of how musical interventions are used in response to individuals', organizations', and societies' very human desire not just to reduce problems, but to function better and to thrive. The caveat, of course, is that whereas such exemplars reveal an apparent universal yearning, they do not represent a step-by-step guide for achieving success. Unfortunately, the world has yet to discover such an assured approach-music-based or otherwise-which is but one reason why this is a time for a more systematic understanding of initiatives worldwide and not just for action-poetic or otherwise.

The following section presents musical initiatives that have been used in situations of extreme tension and consequence. The examples from Venezuela, the United States, Estonia, and South Africa highlight proactive attempts by unified groups to use music to transform fundamental aspects of society. The examples from the Middle East, the former Yugoslavia, Cyprus, and Northern Ireland reveal multicultural initiatives that have attempted to heal society by bringing together opposing factions. Whereas societal challenges often appear most demanding, the dynamics apply equally to organizations.

\section{Collaborative Musical Interventions}

\section{Venezuela: Music Providing the Potential to Escape Poverty}

Venezuela's El Sistema program provides a powerful example of music-based societal development that offers young people a route out of poverty. Founded in 1975 by economist and musician, Jose Antonio Abreu, El Sistema now involves almost 400,000 young people, many from Venezuela's poorest communities, in a network of 500 choirs and orchestras across the country. El Sistema offers young people quality music education along with the individual discipline and community values that come with ensemble music-making. Thus, beyond excellent musical training, the program 
provides participants with the skills to escape poverty and an explicit alternative to the country's endemic crime and drug culture:

Children engaged in the program attain above-average results in school and show a tremendous capacity for collective community action. The orchestra and the choirs, the heart of the program, help create a sense of solidarity. Involvement becomes a weapon against poverty and inequality, violence and drug abuse (Abreu as quoted in Burton-Hill, 2012).

According to Abreu, music teaches "citizenship, social awareness, and an aesthetic sense of life" (as quoted in Apthorp, 2005) and "transmits the highest values - solidarity, harmony, [and] mutual compassion" (as quoted in Tunstall, 2012, p. 273). Ensemble music-making helps to build a culture of cooperation and mutual respect (Uy, 2012).

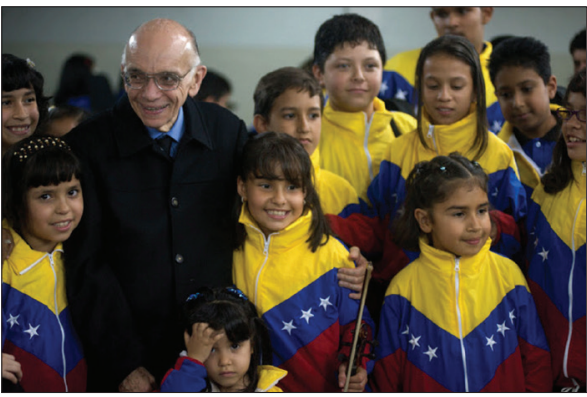

Fig. 1: Gerard Uzcategui, 2012. Jose Abreu with El Sistema participants

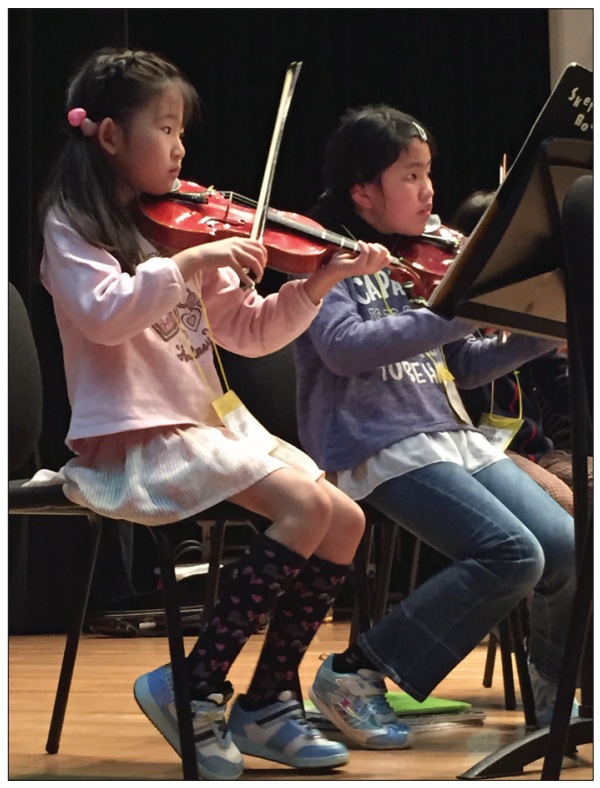

Fig. 2: Photographer unknown, 2015. Young musicians of El Sistema Japan in Fukushima

The El Sistema model is neither culture-specific nor limited to a particular age cohort. The model is now being used not only in Venezuela, but also in more than 50 countries worldwide (http://www.elsistemausa.org/el-sistema-around-the-world. htm). In addition to young people, the El Sistema model is also being employed with adults, some of whom are in the Venezuelan prison system (Asuaje, 2008). 
The original pilot project involved three jails, with each jail constituting a different section of the orchestra-strings, winds, and percussion. The musician-inmates practiced by exchanging $C D$ recordings of each other's sections, and then came together for the first time as a unified ensemble when they performed in concert. In spite of handcuffs and two guards per inmate, the response was enthusiastic. Based on the success of the pilot, the program has been expanded to include more than 7,000 inmates in eight prisons with plans to add more (http://fundamusical.org. ve/education/penitentiary-academic-program/; Grainger, 2011). El Sistema, whether involving young people or adults, demonstrates how community-and a respectful collaborative culture-can be built through ensemble music-making.

\section{United States: Music Humanizing Incarcerated Prisoners}

El Sistema is not the only program that has brought music into extremely challenging organizational settings. The Carnegie Hall-Weill Institute's Musical Connections Program in the United States, for example, also provides musical experiences to inmates. Composer Daniel Levy facilitates one such initiative at New York's Sing Sing Correctional Facility, a maximum security prison. This music composition program assists inmates with an interest and aptitude in music to compose works that the inmate-composers subsequently perform together with professional musicians. Concerts showcasing the compositions are held in and for the community (see Musical Connections, 2014 at http://www.carnegiehall.org/MusicalConnections/). Experts contend that artistic interventions in correctional systems offer prisoners a form of creative engagement that is educational, therapeutic, and rehabilitative (Djurichkovic, 2011; Cohen, 2009). Given that traditional prison philosophy typically is based on punishment and pain, advocacy for positive, arts-based programs requires enormous courage on the part of those who attempt to bring beauty, empowerment, and happiness into the lives of incarcerated individuals (Johnson, 2008). As program director Levy explains:

[Prison] Superintendent Heath said when these men get out of prison they're going to be your neighbors. Who do you want to have as your neighbor? Someone who's been through a process where they're learning to think and work and engage with life or someone who has just been left in their cell for 15 or 20 years. That's a pretty potent argument. (Behind Bars: Music in Sing Sing, 2012 Video)

In addition to arts-based interventions assisting in educating, improving, and rehabilitating incarcerated individuals, Djurichkovic's (2011) review of studies from multiple countries suggests that such programs reduce inmate incident rates, 
decrease recidivism, enhance general well-being, and create opportunities for positive transformative change. Such efforts have been found to benefit inmates, correctional institutions, and, ultimately, the society to which former prisoners return (Cohen, 2009). The Musical Connections program, among numerous other music-interventions in projects around the world, underscores the potentially transformative nature of music and collaborative music-making under the most extreme conditions.

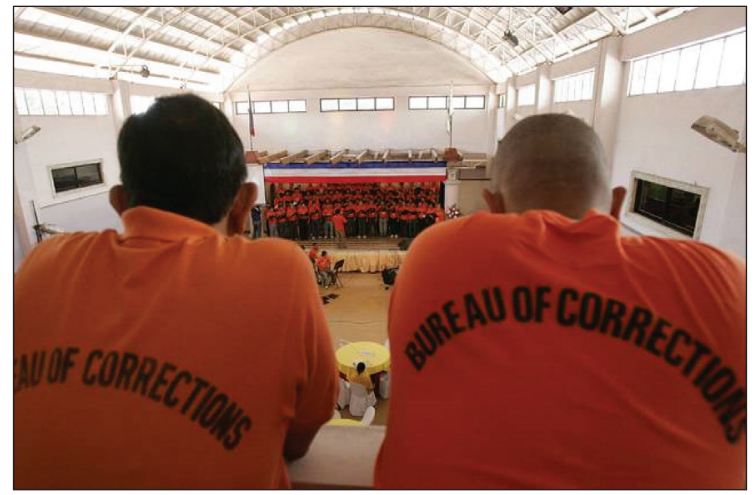

Fig. 3: Aaron Favila, 2010. Inmates at first public performance of Bureau of Corrections Orchestra and Chorale, New Bilibid Prison maximum security compound Muntinlupa, Philippines

\section{Estonia's Singing Revolution: Harmonized Will and Intense Conviction Lead to Freedom}

Among initiatives that strive for societal transformation, numerous exist in which collaborative music-making has promoted unity and solidarity. Such initiatives empower the general public to persevere during times of extreme duress while they work together toward desired change. Aspirational anthems and protest songs sung by large groups of people have a history in almost every culture (Whitehead, 2008). In the United States, for example, the spiritual "Wade in the Water" supported the slaves during the 1800s when they endured enormous hardship fighting for their freedom. A century later, "We Shall Overcome" became the anthem of the U.S. Civil Rights Movement (Whitehead, 2008). Today, Playing for Change, and its de facto anthem, "Stand by Me," exemplifies the ways in which music is supporting global, digitally interconnected communities worldwide. 


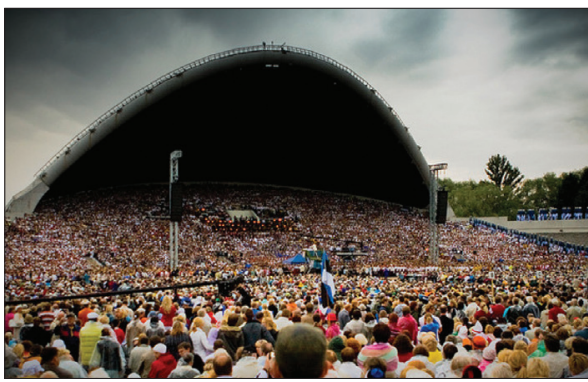

Fig. 4: Kevin Jaanko, 2013. Tallinn Song Festival Grounds, Estonia

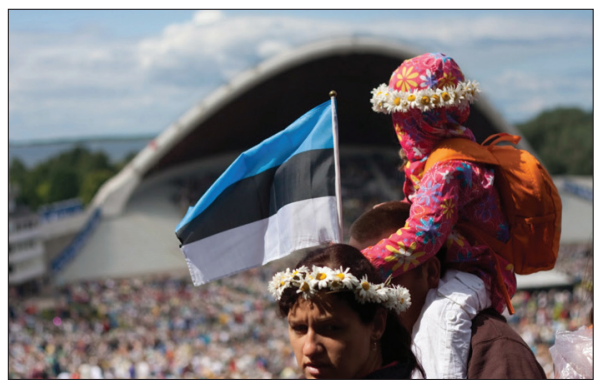

Fig. 5: Ilmars Znotins, 2014. Girl with Estonian Flag, Tallinn Song Festival Grounds, Estonia

Choral singing as a form of non-violent protest during the Soviet occupation of the Baltic States provides a powerful example of a successful music-based societal initiative. Referred to as the Singing Revolution, ${ }^{5}$ song inspired Estonians to persevere against Soviet oppression by finding their united voice and singing until they achieved freedom. Historically, Estonians have always had a strong singing tradition. Since 1869, Estonia held a national song festival every five years to celebrate the folk traditions of each region, with thousands of Estonians of all ages gathering to sing in mass choirs. While the Soviets permitted the festival to continue throughout their almost 50-year occupation, they required the Estonians to sing pro-Soviet songs. In response, the Estonians adopted their own folk songs as de facto national anthems, musical symbols of their fight for freedom. With the rise of glasnost ("free speech") in 1988, singing became an essential form of non-violent protest. In June 1988, 100,000 people spontaneously gathered for seven nights to sing songs that had previously been banned by the Soviets. Confident that the Soviet military would not attack the gathered singers, particularly with the world watching, the Estonians realized the real power of their voices. Three months later, 300,000 Estonians held a massive demonstration on the song-festival grounds in Tallinn, singing protest songs accompanied by political speeches demanding the restoration of Estonian sovereignty. After years of oppression and struggle, Estonia achieved independence in 1991. Music succeeded in binding Estonians together in a community of harmonized will and intense conviction. Through song, they not only found the sustaining power of hope, but also the motivating strength that ultimately led them to freedom. 


\section{South Africa: A Revolution in Four-Part Harmony ${ }^{6}$}

Similar to Estonia, music united and sustained Black South Africans during the repressive apartheid regime. For 50 years, song formed a powerful narrative in their struggle against oppression. Referred to as "a revolution in four-part harmony," musicians, singers, and composers-all poetic activists-became the voices of leadership, confronting the State with their lyrics and powerfully advocating political change. Songs, chants, and the toyi-toyi war dance served to mobilize millions of South Africans. As one activist described, "The toyi-toyi was our weapon. We did not have the technology of warfare, the tear gas and tanks, but we had this weapon" (Blackstone, 2008). Music, as a form of underground communication, united the oppressed and gave them inspiration to continue fighting. At a visceral level, the apartheid regime understood the Amandla-the power-of music. As Plato expressed it in The Republic more than two millennia earlier, "Any musical innovation is full of danger to the whole State, and ought to be prohibited.... [W] hen modes of music change, the fundamental laws of the State always change with them" (Plato, trans. 1948, 360BCE, Book IV).

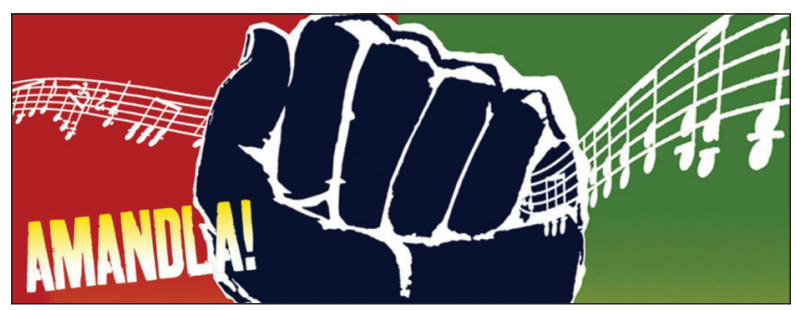

Fig. 6: Official Movie Poster, 2002. Amandla! A Revolution in Four-Part Harmony

The South African police and military constantly arrested musician-activists, revoked their passports, and censored their songs and radio broadcasts. Music and the courage of South Africa's poetic activists played an instrumental role in shaping the political struggle and ultimately in ending apartheid (see Schumann, 2008; Makky, 2007; among others). 


\section{Music Healing Society: Multicultural Ensembles Transforming Enmity Into Friendship}

Whereas the previous examples from Venezuela, the United States, Estonia, and South Africa describe how music supported like-minded people in achieving significant goals, the following examples reveal how music can bring together people from multiple cultures who are publicly viewed as enemies. In these examples from the Middle East, Cyprus, Northern Ireland, and the former Yugoslavia, the musical interventions aim to heal the damage and divisiveness that both causes conflict and that conflict causes.

In each example of poetic activism, one must respect the profound courage it takes for musicians to publicly be seen together with "the enemy," often in ways that the general public not only rejects, but, for the most part, remain unimaginable. History is littered with cases of individuals who have paid the ultimate price for such forward-thinking displays of courageous community building. Such attacks are not just perpetrated by supposed enemies, but all too often by extremists from their own side who view the artists, musicians, and poetic activists as traitors for collaborating with the enemy. In all cases, whether involving world-renowned political leaders or relatively unknown poetic activists, the act of joining with "the other" to co-create music and a better world is always inherently risky and requires profound courage.

\section{Middle East: West-Eastern Divan Orchestra Performing the Poetry of Peace}

While the initiatives in Estonia and South Africa engaged and influenced the general public, the West-Eastern Divan Orchestra primarily targets a subset of the population, elite Arab and Israeli musicians. The Orchestra focuses on high-profile collaborative music-making to create communication and relationship bridges among people from opposing cultures in the Middle East conflict. This world-class orchestra of 19- to 25-year-olds was the inspiration of Israeli pianist-conductor Daniel Barenboim and the late Palestinian literary scholar Edward Said. The orchestra has both an Israeli and an Arab concert master and players from opposing sides of the conflict share each music stand, as well as a number of Spanish musicians who act as "neutral partners." Every summer since 1999, orchestra members have met for a four-week intensive rehearsal workshop.? Throughout the workshop, the musicians eat, sleep, and share their daily lives together. Each evening they join in social and political discussions. 
The supposed adversaries then tour as a unified orchestra. The goal is for participants to take home positive experiences from engaging with the "enemy" and for those experiences to subsequently have a cascading impact on their family and friends.

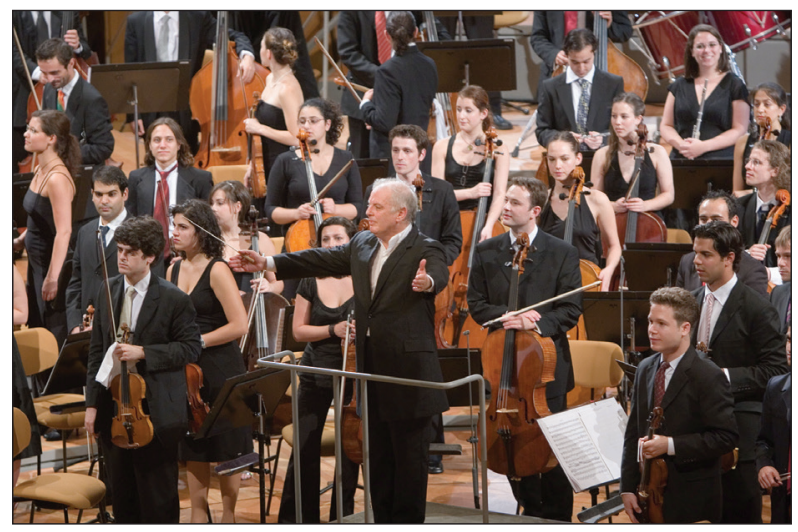

Fig. 7: Luis Castilla, 2006. Daniel Barenboim with West-Eastern Divan Orchestra

Less bad is not good. Less ugly is not beautiful. Similar to most musical ensembles that attempt to unite societal enemies, the West-Eastern Divan Orchestra attempts to create beauty, not merely to reduce the ugliness of animosity and war. In viewing music as social medicine, physician David Washington notes that

...permanent healing in [the Middle East]... can occur only with the institution of social structures that provide a stable source of positive and novel interaction; that is, peace depends on activities that can construct society rather than destroy it. The [West-Eastern] Divan Orchestra does just that. (Washington \& Beecher, 2010, p. 131)

The West-Eastern Divan Orchestra is clearly responding to singer-songwriter Phil Ochs' admonishment: "In these ugly times, the only true protest is beauty." Their choice of music reflects the West-Eastern Divan Orchestra's musicians' profound understanding of their role and voice in the world: "Beethoven gave humanism a sound."

Admittedly, critics have questioned the ability of the West-Eastern Divan Orchestra to achieve its ambitious non-musical agenda, disparagingly regarding it as a "problematic utopia" (Beckles Willson, 2009a, p. 21). Drawing on more contemporary understandings of how organizations and societies change, we can now appreciate that the West-Eastern Divan Orchestra is best understood as a positive deviant (Spreitzer \& Sonenshein, 2004; Pascale \& Sternin, 2010) and not a "problematic utopia." 
Evidence to date suggests that attitudes and behaviours toward fellow musicians have, in fact, become more positive, but that similar positive changes only rarely extend beyond the members of the orchestra (Beckles Willson, 2009a, 2009b; Riiser, 2010). Supporting the contact hypothesis (Allport, 1954) on which the West-Eastern Divan Orchestra was founded, Barenboim recalls a personal performance he gave in Ramallah for 300 Palestinian children. After the concert, a young girl told Barenboim how happy she was that he was in Ramallah. When asked why, she responded that he was the first "thing" from Israel she had ever seen in Ramallah that was neither a soldier nor a tank. While no individual concert can end the conflict, as Barenboim states, "at least for a couple hours, it managed to reduce the level of hatred to zero" (Barenboim as quoted in Smaczny, 2005; see also Barenboim \& Said, 2004 and Daniel Barenboim's Edward W. Said Lecture, 2015).

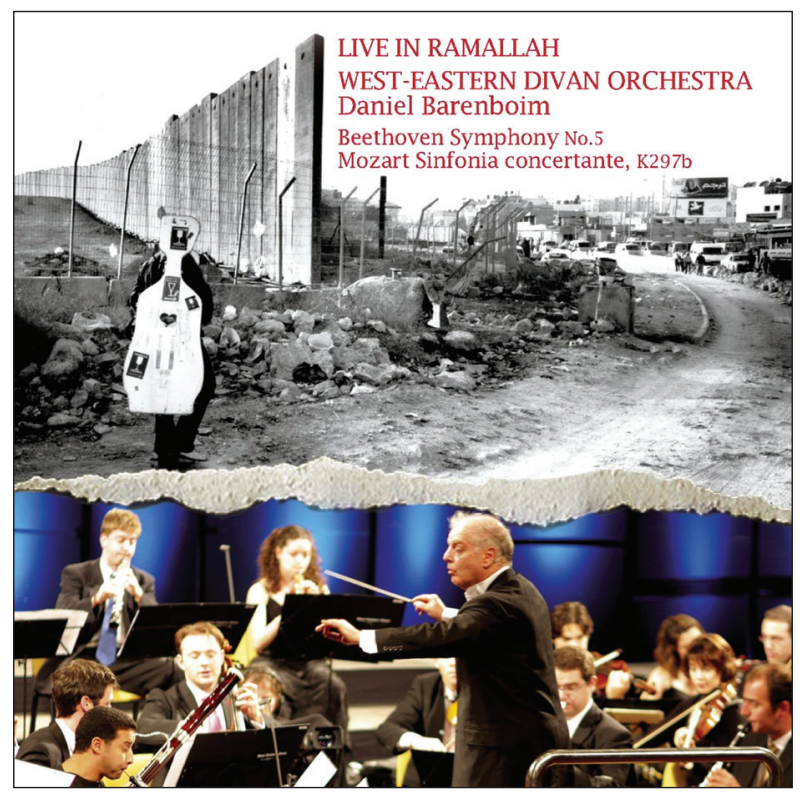

Fig. 8: Front cover from CD Recording, 2006

In 2015, the Rand Corporation (2015) estimated that there would be a net peace dividend of more than $\$ 150$ billion if the Israelis and Palestinians agreed to a twostate political resolution to their conflict. Even with such extraordinary political and economic benefits, no solution has been reached. Perhaps relative to the broader society, neither the political nor the economic discourse in the Middle East is quite ready for Beethoven's or the Orchestra's message of collaborative humanism. 


\section{Bi-Communal Choir for Peace: Greek and Turkish Cypriots' Daring to Sing Across the Green Line}

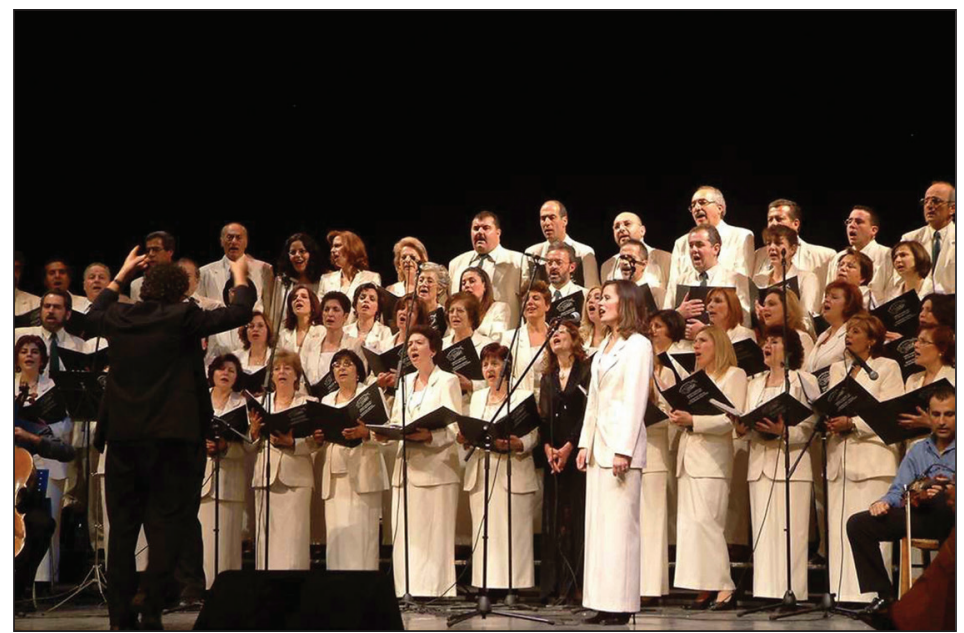

Fig. 9: Photographer unknown, 2004. Bi-Communal Choir for Peace, Cyprus

The Bi-Communal Choir for Peace provides yet another example of collaborative music-making in the face of societal conflict. Exhibiting profound moral courage, Greek and Turkish Cypriot musicians cross the Green Line, a demilitarized zone that divides the country, to rehearse and perform together (Ungerleider, 1999). By singing traditional songs of Cyprus, performed in both languages, and by commissioning works by Greek composers and Turkish lyricists and vice versa, these musician-activists present a powerful message reflecting their unique identities and interconnected roots. The symbolism and embodiment of their plea for trust, reconciliation, and affirmation became highly visible once again when the Choir recently joined cultural, religious, business, and trade union groups to sing at the 40th-anniversary effort to achieve reunification (see http://choirforpeace.weebly.com/).

\section{Northern Ireland: Different Drums Create Synergies Born in Unique Identities}

Similarly reflecting courage, Different Drums of Ireland brings together musical instruments carrying immense symbolism from both sides of the conflict. The group purposely uses the lambeg, a large military-style Protestant/Unionist drum, and the 
bodhran, a smaller stick-played Catholic/Nationalist hand-drum. During the conflict in Northern Ireland, referred to as "The Troubles," the consequences of publicly playing the wrong drum could result in being beaten or even killed. Members of Different Drums have not been immune to such threats as their music-making challenges deeply held prejudices. Once, for example, when Different Drums played in Belfast to a workingclass Protestant audience, all their bodhrans were smashed. Despite such hostility, the group continues its efforts to divest the drums of divisive political connotations and invest them with a new symbolism of coexistence that can only come from co-creation.

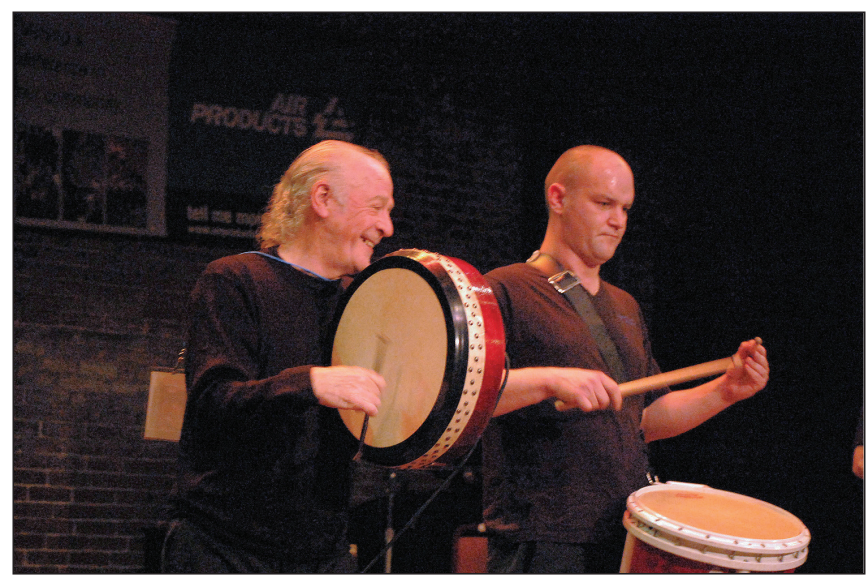

Fig. 10: indyCelt (n.d.). Roy Arbuckle and Richard Campbell Different Drums of Ireland

Much like the West-Eastern Divan Orchestra and other music-based initiatives in regions of high conflict, Different Drums focuses on creating novel, positive interactionsand not simply on reducing ugliness. By uniting the distinct voices and rhythms of the two drums, the ensemble shows how unique co-created identities can be used to produce synergy and create harmony in their performances as well as in society.

\section{Bosnia-Herzegovina: Pontanima Choir Singing Sacred Synergy}

The Pontanima Choir highlights how collaborative music-making fosters reconciliation and healing following conflict. In Latin, pontanima means "soul bridge." The Pontanima Choir was founded in early 1996 just as the Bosnian war was ending, when a Catholic church in Sarajevo could not find enough members for its choir. Choir director Josip Katavić asked the parish priest, Father Marković, if it might be possible to invite "the others" to augment his choir's vocal ranks. That courageous 
frame-breaking request resulted in a choir made up of Christians, Jews, and Muslims who came together to sing each other's sacred music. The unprecedented repertoire and inter-faith membership of the Choir catalyzed both outrage and support from the members' respective communities. In reflecting on the unorthodox approach, Father Marković understood that the Choir was encouraging the most important form of communication and ecumenism. "[Singing each other's sacred music] ...doesn't mean we lose our identity, [but rather] that we all win. We have a new mirror" (Marković as quoted in Gienger, 2003). "The diversity forms a beautiful, ecumenical mosaic, which eliminates mistrust and xenophobia, and restores communication, cooperation, dialogue, coexistence, pluralism, empowerment and enculturation" (Marković, 2004).

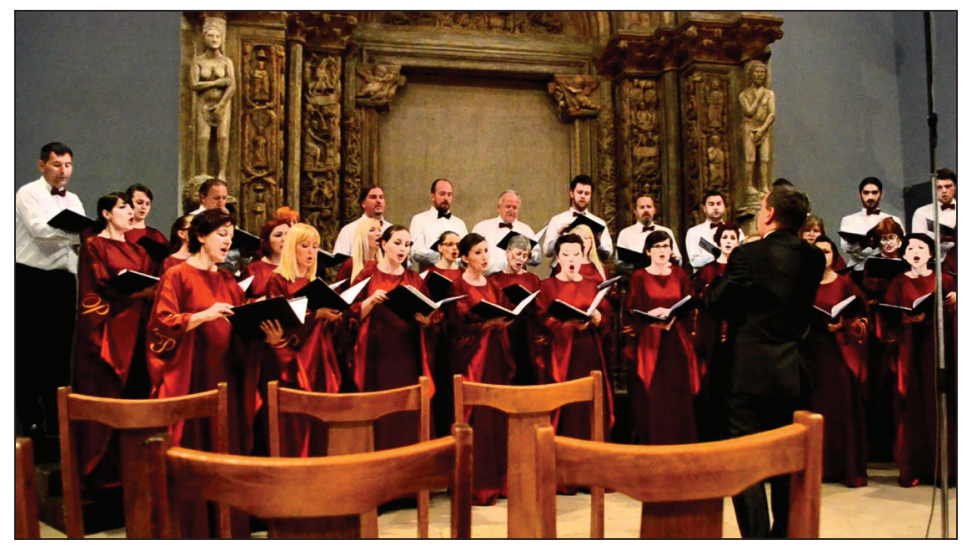

Fig. 11: Photographer unknown, 2011. Pontanima Choir of Sarajevo, Bosnia-Herzegovina

The Choir has not only become an accomplished ensemble, but also a dynamic community that models the possibility of an integrated society for all of BosniaHerzegovina. Similar to Different Drums in Northern Ireland, the Pontanima Choir does not just talk ecumenism, it lives and performs it. Its music spreads a message of enlarging the self by embracing the other. As Father Marković (2004) explains:

The song of our neighbor affects us and we receive it and grow through it. Likewise, our song becomes our neighbor's heritage and impacts their growth. In that interwoven spirituality and in the discovery of our own reflection in the other, no one loses, but instead it is the only way to grow. 
The Pontanima Choir has won numerous peace prizes, despite ongoing opposition. By singing its aspirations, the Choir inspires participants, audiences, and community members alike with its message of unity, synergy, and the possibility of a vibrant, transcending, and shared future.

\section{Sarajevo: A Cellist Reclaims Humanity in the Face of War}

A particularly compelling example of musical leadership and individual courage took place in Sarajevo during the Bosnian War. In response to sniper and mortar attacks on civilians during the siege of Sarajevo, world-renowned cellist Vedran Smailović, formally dressed in his tuxedo and tails, positioned himself in the ruins of the National Library, defying sniper fire, and played. People gathered to listen. Uplifted and encouraged by his music, humanity, and courage, they repeatedly asked him to play. Smailović returned to this and other sites and played again and again in honor of the people who had been killed in the conflict (Smailović, 1998; CBC News,2008; Sharrock, 2008).

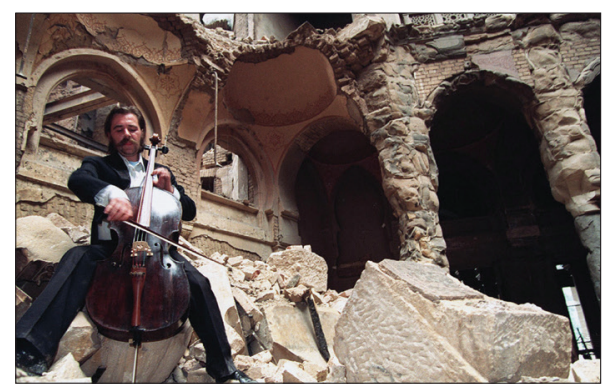

Fig. 12: Mikhail Estafiev, 1992. Vedran Smailovic, the "Cellist of Sarajevo," playing in the destroyed Sarajevo National Library

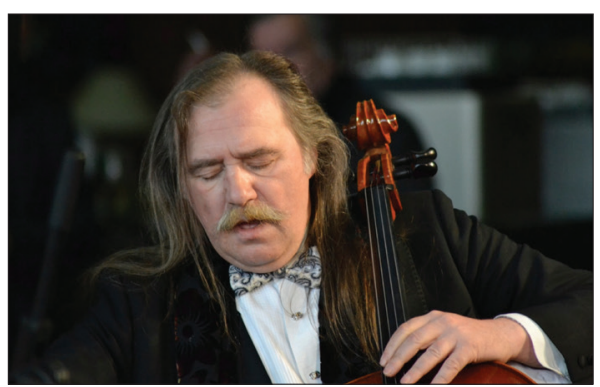

Fig. 13: Photographer unknown, 2012. Vedran Smailovic's return to Sarajevo

Smailović's actions caught the attention of the world press, exposing the debilitating, yet all too commonly held, nature of their perspective. During a lull in the shelling, an incredulous journalist confronted Smailović, demanding: "Aren't you crazy for playing music while they are shelling Sarajevo?" (Lederach, 2005, p. 156). Smailović countered the widely held illogic of the journalist's perspective with his reply: "Playing music is not crazy. Why don't you go ask those people if they are not crazy shelling Sarajevo while I sit here playing my cello" (Smailović, 1998 cited in Lederach, 2005,p. 156). Smailović's cello was not a tool to end war. Rather, his music reclaimed life in the face of war. Music reminds us that there is life beyond war, humanity beyond degradation, beauty beyond ugliness. Scholar and poet Swati Chopra (2007) captures the profound meaning and impact of Smailović's poetic activism: 
Smailović played to ruined homes, smouldering fires, [and] scared people hiding in basements. He played for human dignity that is the first casualty in war. Ultimately, he played for life, for peace, and for the possibility of hope that exists even in the darkest hour.

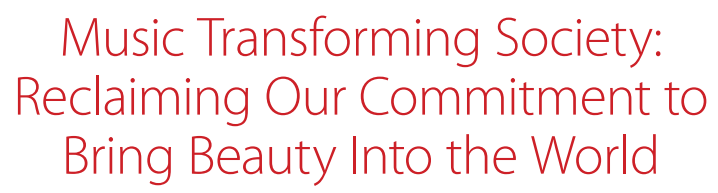

The world is rife with challenges that so seriously and pervasively threaten the stability and sustainability of the planet that many suggest that the future of civilization, as we know it, is in question. Faced with such a reality, we cannot help but appreciate Albert Einstein's prescient observation that is as true today as it was more than a half century ago when he first stated that, "We cannot solve problems by using the same kind of thinking we used when we created them." Society needs new approaches that can only be found "outside of the mainstream of international political traditions, discourse, and operational modalities (Lederach, 1997, p. 25)." Contemporary society and the challenges it faces demand innovation. Global society urgently requires the development of ideas and practices that go beyond conventional economic, political, legal, and military approaches with their often narrow focus primarily on reducing ugliness (see Lederach, 1997; Ippolito, 2015). Less bad is not good. Now is the time to invoke beauty, and not simply continue with attempts to reduce ugliness.

This article has presented a range of music-based societal interventions that highlight the dynamics of music and ensemble music-making that appear robust enough to transform both major and day-to-day organizational and societal dysfunction. Rather than repeating past approaches and expecting different results, music-based interventions go beyond most previously tried approaches and their repeated failures to explore the potential for a different kind of future success. The stakes are very high. Notwithstanding, guarantees of success remain elusive (see Bergh, 2007, 2008, 2010, 2011; Beckles Willson, 2009a; and Bergh \& Sloboda, 2010, among others). Given their history, music- and other arts-based approaches appear to offer hope for transforming conflict, developing more generative organizational and societal cultures, and addressing serious world challenges (see Ippolito, 2015). 


\section{LEARN MORE}

\section{How El Sistema Changes Lives Through Music}

- Changing Lives Through Music: CBS 60 Minutes

- Tocar y Luchar / (To Play and to Fight): Documentary

A Higher Key: Music Program Helps Kids Learn

- El Sistema: Juvenile Detention / Jail

Behind Bars: Music at Sing Sing

Role of Music at Sing Sing Correctional Facility

\section{Estonia's Singing Revolution}

Singing From the Same Hymn Sheet: David Drummond

- The Singing Revolution

- The Singing Revolution: A Single Nation. A Million Voices. The Fall of an Empire

\section{South Africa: Music Supporting Revolutionary Change}

South Africa: A Revolution in Four-Part Harmony

Soweto Freedom Song \& Toyi-Toyi Protests

Toyi-Toyi Protests in South Africa During Apartheid

West-Eastern Divan Orchestra: The Middle East

An Introduction to the West-Eastern Divan Orchestra

Inside Barenboim's West-Eastern Divan Orchestra

Daniel Barenboim: Why I'm Proud of My Orchestra

Daniel Barenboim: Spaces of Dialogue

\section{Cyprus: Bi-Communal Choir}

Choir Sings at Voroklini Town Hall

\section{Different Drums of Ireland}

Different Drums of Ireland Performing Biddy McDole at Big Top Chautauqua

Different Drums Talk About Their Ethos and Background

Different Drums of Ireland 


\section{Pontanima Choir: Singing Sacred Synergy}

Pontanima: Rachmaninoff's Bogorodice Djevo, Sarajevo

Pontanima: Cuando El Rey Nimrod

\section{The Cellist of Sarajevo}

20 Years After the Start of the Siege, A Return To Sarajevo:

Radio Free Europe (background)

Cellist Vedran Smailovic Playing Adaggio by Albinoni

The Cellist of Sarajevo: Steve Galloway Interview

\section{Notes}

1. Adapted from Ippolito and Adler (2015) in Johansson Sköldberg, Woodilla, and Berthoin Antal (2015). Original research on collaborative music-making in high conflict situations drawn primarily from Ippolito (2008).

2. Ben Zander conducts the Boston Philharmonic and serves as a guest conductor for orchestras worldwide.

3. Title of Adler's 2009 art exhibition at The Banff Centre, where she was an artist in residence.

4. The literature suggests that extreme cases are valuable in revealing phenomena that are often camouflaged in less extreme, more common, and therefore, more familiar, circumstances (Cohen \& Crabtree, 2006; Mills, Durepos, \& Wiebe, 2010).

5. The Singing Revolution is commonly used to refer to events between 1987 and 1991 that led to the restoration of independence in Estonia, Latvia, and Lithuania (Thomson, 1992; Ginkel, 2002). The term was coined by Estonian "poetic activist" (activist and artist), Heinz Valk, and published in an article a week after the June 10-11, 1988 spontaneous mass night-singing demonstrations at the Tallinn Song Festival Grounds (Vogt, 2004, as cited at: http://en.wikipedia.org/wiki/Singing_Revolution). Also see Vesilind (2008) and The Singing Revolution, the 2006 documentary film by James Tusty and Maureen Castle Tusty.

6. From the 2002 documentary Amandla! A Revolution in Four-Part Harmony, written and directed by Lee Hirsch, which presents interviews, archival footage, and filmed performances highlighting the role that music played in South Africa's struggle 
against apartheid. Singer-activists include such voices as Vuyisile Mini, Miriam Mekeba, Dorothy Masuka, and Roger Lucey. Also see the 2013 BBC documentary by Canadian filmmaker Jason Bourque, "Music for Mandela: A Legacy with a Backbeat," depicting the same history and impact.

7. Since 2002, the West-Eastern Divan Orchestra has made its home in Seville, Spain and been supported by the Andalusian Regional Government (Junta de Andalucía).

8. As cited in "An Introduction to the West-Eastern Divan Orchestra." Retrieved from https://www.youtube.com/watch?v=K22pkacxfN0

9. Every effort is being made to acknowledge the copyright holders. The authors apologize for any unintentional omissions and would be pleased, in such cases, to place an acknowledgment in future reprints of this article.

\section{References}

Adler, N.J. (2006). The arts and leadership: Now that we can do anything, what will we do? Academy of Management Learning and Education, 5(4), 466-499.

Adler, N.J. (2011). Leading beautifully: The creative economy and beyond. Journal of Management Inquiry, 20(3), 208-221.

Adler, N.J. (2010). Going beyond the dehydrated language of management: Leadership insight. Journal of Business Strategy, 31(4), 90-99.

Adler, N.J. (2015). Finding beauty in a fractured world: Art inspires leaders-Leaders change the world. Academy of Management Review, 40(3), 480-494.

Allport, G. W. (1954). The nature of prejudice. Cambridge, MA: Perseus Books.

Apthorp, S. (2005). Classical escape from life on the mean streets. Financial Times. Retrieved from http://www.ft.com/intl/cms/ s/0/c4d1458c-0228-11da-9481-00000e2511c8. html\#axzz1qVxTRJCc

Asuaje, L. (2008). El Sistema in penitentiaries, El Nacional. Translated from Spanish by José Bergher. Retrieved from https://tipom.wordpress.com/2008/05/27/8/
Barenboim, D., \& Said, E.W. (2004). Parallels and paradoxes. New York: Vintage Books.

Beckles Willson, R. (2009a). Whose utopia? Perspectives on the West-Eastern Divan Orchestra. Music \& Politics, 3(2), 1-21.

Beckles Willson, R. (2009b). The parallax worlds of the West-Eastern Divan Orchestra. Journal of the Royal Musical Association, 134(2), 319-347.

Benzon, W. (2001). Beethoven's anvil. New York: Basic Books.

Bergh, A. (2007). I'd like to teach the world to sing: Music and conflict transformation. Musicae Scientiae, 11(Suppl. 2), 141-157.

Bergh, A. (2008). Everlasting love: The sustainability of top-down vs bottom-up approaches to music and conflict transformation. In S. Kagen and V. Kirchberg (Eds.), Sustainability: A new frontier for the arts and cultures (pp. 351-382). Bad Homburg, Germany: VAS-Verlag.

Bergh, A. (2010). I'd like to teach the world to sing: Music and conflict transformation. PhD. University of Exeter. 
Bergh, A. (2011). Emotions in motion: Transforming conflict and music. In I. Deliege \& J.W. Davidson (Eds.), Music and the mind (Essays in honour of John Sloboda) (pp. 363-378). Oxford: Oxford University Press.

Bergh A., \& Sloboda, J. (2010). Music and art in conflict transformation: A review. Music and Arts in Action, 2(2), 2-17.

Blackstone. (2008). 'The Toyi-Toyi of South Africa', Power to the People [blog] February 18. Retrieved from http://power-2-people. blogspot.ca/2008/02/toyi-toyi-of-southernafrica.html

Burton-Hill, C. (2012). José Antonio Abreu on Venezuela's El Sistema miracle. The Guardian. Retrieved from http://www.theguardian. com/music/2012/jun/14/abreu-el-sistemavenezuela-interview-clemency-burton-hill

Chopra, S. (2007). The cellist of Sarajevo. Retrieved from http://www.lifepositive. com/the-cellist-of-Sarajevo

Cohen, C.E., Gutiérrez Varea, R., \& Walker, P.O. (Eds.). (2011). Acting together: Performance and the creative transformation of conflict. New York: New Village Press

Cohen D., \& Crabtree, B. (2006). Qualitative research guidelines project. Princeton: Robert Wood Johnson Foundation. Retrieved from http://www.qualres.org/HomeExtr-3808. html

Cohen, M.L. (2009). Choral singing and prison inmates: Influences of singing in a prison choir. Journal of Correctional Education, 60(1), 52-65.

Deliege, I., \& Davidson, J. (Eds.). (2011). Music and the mind (Essays in honour of John Sloboda) (pp. 363-378). Oxford University Press.

Djurichkovic, A. (2011). Art in prisons: A literature review of the philosophies and impacts of visual arts programs for correctional populations. University of Technology, Sydney (UTS), Shopfront Student Series 3, UTS e-PRESS.

Freeman, W. (2000). A neurobiological role of music in social bonding. In N.L. Wallin, B. Merker, \& S. Brown (Eds.), The origins of music. Cambridge, MA: MIT Press.

Gergen, K.J. (1999). An invitation to social construction. Thousand Oaks, CA: Sage.
Gienger, V.G. (2003). Interfaith choir builds 'spiritual bridges to heal division of war.' Religion News Service. Retrieved from http://archives.religionnews.com/politics/ government-and-politics/news-featureinterfaith-choir-builds-spiritual-bridges-toheal-divisions-of

Ginkel, J. (2002). Identity construction in Latvia's "singing revolution": Why inter-ethnic conflict failed to occur. Nationalities Papers, 30(3), 403-433.

Grainger, S. (2011). Venezuela prison orchestra gives hope to inmates. BBC News. Retrieved from http://www.bbc.com/news/ world-latin-america-14050825?print=true

Ippolito, L.M. (2008). Collaborative vocal music-making - An innovative approach to conflict resolution and peacebuilding. Masters. York University.

Ippolito, L.M. (2015). Changing our tune: A musicbased approach to teaching, learning and resolving conflict. PhD. York University.

Ippolito, L., \& Adler, N.J. (2015). From aspiration to evidence: Music, leadership and organizational transformation. In Ulla Johansson Sköldberg, Jill Woodilla, \& Ariane Berthoin Antal (Eds.), Artistic interventions in organizations: Current practice and theory ( $\mathrm{pp}$. 125-150). London: Routledge.

Johansson Sköldberg, U., Woodilla, J., \& Berthoin Antal, A. (Eds.). (2015). Artistic interventions in organizations: Current practice and theory. London: Routledge.

Johnson, L.M. (2008). A place for art in prison: Art as a tool for rehabilitation and management. Southwest Journal of Criminal Justice, 5(2), 100-120.

Lederach, J. P. (1997). Building peace: Sustainable reconciliation in divided societies. Washington, DC: United States Institute of Peace Press.

Lederach, J. P. (2005). The moral imagination: The art and soul of building peace. New York: Oxford University Press. 
Marković, I. (2004). The history of Pontanima is a short story of reconciliation in BosniaHerzegovina. Report on the workshop 'conflict resolution from below'. ASEM People'sForum V Hanoi, [online] 6-9 September. Retrieved from http://www.asi enhaus.de/public/archiv/marcovictext.pdf.

Makky, N. (2007). Song in the anti-apartheid and reconciliation movements in South Africa. Masters. Ohio State University.

McNeill, W.H. (1997). Keeping together in time. Cambridge, MA: Harvard University Press.

Mills, A.J., Durepos, G., \& Wiebe, E. (2010). Encyclopedia of case study research. Thousand Oaks: Sage.

Musical Connections. (2014). Carnegie Hall-Weill Institute. Retrieved from http://www.carne giehall.org/MusicalConnections

Pascale, R., \& Sternin, J. (2010). The power of positive deviance: How unlikely innovators solve the world's toughest problems. Boston: Harvard Business Press.

Rand Corporation. (2015). Israelis stand to gain $\$ 120$ billion, Palestinians $\$ 50$ billion in two-state solution over next decade. Press Release, June 8.

Riiser, S. (2010). National identity and the WestEastern Divan Orchestra. Music and Arts in Action, 2(2), 19-37.

Schumann, A. (2008). The beat that beat apartheid: The role of music in the resistance against apartheid in South Africa. Stichproben. Wiener Zeitschrift für kritische Afrikastudien Vienna Journal of African Studies, 8(14), 17-39.

Smailović, V. (1998). Memento Mori Albinoni Adagio. In Sarajevo Belfast [sleeve notes]. West Chester, PA: Appleseed.

Smaczny, P. (Director). (2005). Knowledge is the beginning. (Documentary Film)

Spreitzer, G.M., \& Sonenshein, S.T. (2004). Toward a construct definition of positive deviance. American Behavioral Scientist, 47, 828-847.

Thomson, C. (1992). The singing revolution: $A$ political journey through the Baltic States. London: Joseph.
Tillotson, K. (2014). "A higher key: Music program helps kids learn new skills." Star Tribune. Retrieved from http://www.startribune. com/music-program-helps-kids-learn-newskills/261563421/

Tongeren, P. van (Ed.). (1999). People building peace: 35 inspiring stories from around the world. Utrecht, Netherlands: European Centre for Conflict Prevention.

Tunstall, T. (2012). Changing lives: Gustavo Dudamel, El Sistema, and the transformative power of music. New York: W. W. Norton \& Company.

Ungerleider, J. (1999). My country is cut in two. In P. van Tongeren (Ed.), People building peace: 35 inspiring stories from around the world (pp. 297-301). Utrecht, Netherlands: European Centre for Conflict Prevention.

Urbain, O. (Ed.). (2008). Music and conflict transformation: Harmonies and dissonances in geopolitics. New York: I. B. Tauris.

Uy, M. (2012). Venezuela's national music education program El Sistema: Its interactions with society and its participants' engagement in praxis. Music and Arts in Action, 4(1), 5-21.

Vesilind, P. (2008). The singing revolution. Tallinn, Estonia: Varrak.

Vogt, H. (2004). Between utopia and disillusionment. New York: Berghahn Books.

Washington, D.M., \& Beecher, D.G. (2010). Music as social medicine: Two perspectives on the West-Eastern Divan Orchestra. New Directions for Youth Development, Spring Issue (125), 127-140.

Welch, D., \& LeBaron, M. (2006). Arts, creativity and intercultural conflict resolution literature and resource review. Vancouver: University of British Columbia.

Whitehead, B. (2008). We shall overcome: The roles of music in the US civil rights movement. In O. Urbain (Ed.), Music and conflict transformation: Harmonies and dissonances in geopolitics (pp. 78-92). London: I. B. Tauris.

Zander, R.S., \& Zander, B. (1998). Leadership: An art of possibility. Cambridge, MA: Harvard Business Press. 


\section{Photo Image References 9}

Figure 1: $\quad$ Uzcategui, G. (2012). Jose Antonio Abreu with El Sistema participants. Retrieved from https://culturaldiplomacyinlatinamerica.files.wordpress.com/2013/05/20120523_ el-sistema_abreu.jpg

Figure 2: [Photographer unknown]. (2015). Young musicians of El Sistema Japan in Fukushima, Soma [digital image]. Retrieved from http://brianlauritzen.com/tag/ el-sistema-japan/

Figure 3: $\quad$ Favila, A. (Photographer). (2010). Filipino inmates watch during the first public performance of the Bureau of Corrections Orchestra and Chorale, New Bilibid Prison maximum security compound Muntinlupa, Philippines. Retrieved from http://www.sandiegouniontribune.com/news/2010/jun/15/philippine-prison -orchestra-in-1st-public-concert/

Figure 4: Jaanko, K. (Photographer). (2013). Tallinn Song Festival Grounds, Estonia. Retrieved from https://www.purdue.edu/convocations/the-singing-revolution/

Figure 5: Znotins, I. (Photographer). (2014). Girl with Estonian Flag, Tallinn Song Festival Grounds, Estonia. Retrieved from http://francescoolcelli.blogspot.com/2014/07/ estonias-revolutionary-spirit-embodied.html

Figure 6: [Official Movie Poster]. (2002). Amandla! A Revolution in Four-Part Harmony (Hirsch, 2002) [digital image]. Retrieved from http://www.globalexchange.org/events/ movie-screening-amandla-revolution-four-part-harmony

Figure 7: $\quad$ Castilla, L. (Photographer) (2006). Daniel Barenboim with West-Eastern Divan Orchestra. Retrieved from http://www.prize.gulbenkian.pt/PreviousEditions Winners/Prize2012

Figure 8: $\quad$ [Front cover from CD Recording]. (2006). Live in Ramallah. West-Eastern Divan Orchestra. Retrieved from http://www.discogs.com/West-Eastern-Divan-OrchestraDaniel-Barenboim-Beethoven-Mozart-Live-In-Ramallah-Beethoven-Symphony-N/ release/6775109

Figure 9: [Photographer unknown]. (2004). Bi-Communal Choir for Peace, Cyprus. Retrieved from http://www.unitedcyprusplatform.org/concert-cyprus.php

Figure 10: $\quad$ indyCelt (Photographer). (n.d.). Roy Arbuckle and Richard Campbell - Different Drums of Ireland. Retrieved from https://www.flickr.com/photos/indycelt/3110619092

Figure 11: [Photographer unknown]. (2011). Pontanima Choir of Sarajevo, Bosnia, and Herzegovina. Retrieved from https://www.youtube.com/watch?v=7IJX388U3Q4

Figure 12: Estafiev, M. (Photographer). (1992). Vedran Smailovic, "The Cellist of Sarajevo," playing in the destroyed Sarajevo National Library, 1992. Retrieved from http://media2.snbcnews.com/i/newscms/2014_19/429201/140508-sarajevo-cellist-10a_5f6f2e3b25 a32919f9c1e691d7f7d355.jpg

Figure 13: [Photographer unknown]. (2012). Vedran Smailovic return to Sarajevo, 2012. Retrieved from https://tulliobugari.wordpress.com/2012/04/09/give-peace-a-chance/ 


\section{Film, Video, and Music References}

\section{El Sistema, Venezuela}

Simon, B. (Reporter). (2008, July 16). El Sistema: Changing Lives through Music. In H. A. Radliffe II (Producer), 60 Minutes. [Video file]. Retrieved from http://www.cbsnews.com/news/ el-sistema-changing-lives-through-music/

Arcaya, P. M. (Producer), Arvelo, A. (Director). (2006). Tocar y Luchar [DVD]. Retrieved from http:// www.snagfilms.com/films/title/tocar_y_luchar_to_play_and_to_fight

Brewster, D. [Star Tribune]. (2014, June 3). A higher key: Music program helps kids learn new skills [Video file]. Retrieved from http://www.startribune.com/musicprogram-helps-kids-learn-new-skills/261563421/

The most inclusive music education system ever! (2008, May 2). El Sistema: Juvenile Detention/Jail [Video file]. Retrieved from http://www.youtube.com/watch?v=c28oypf3ZPc

\section{Prison, United States}

Carnegie Hall. (2012, July 30). Behind Bars: Music at Sing Sing [Video file]. Retrieved from https:// www.youtube.com/watch?v=TBYRMgPny-k

\section{Estonia}

TEDx Talks. (2013, June 28). Singing from the Same Hymn Sheet: David Drummond at TEDxHousesofParliament [Video file]. Retrieved from https://www.youtube.com/ watch? $v=q R m h x c 27 E q M$

Allfilm. (2012, January 6). "Singing Revolution" 2006 Trailer [Video file]. Retrieved from https://www. youtube.com/watch?v=pm3yzSN8aVk

Cram, B., Talvik, A., \& Tibbo-Hudgins, P. (Producers), Tusty, J., \& Castle Tusty, M. (Directors). (2006). The Singing Revolution [DVD]. Retrieved from http://singingrevolution.com

\section{South Africa}

Boneza, R.N. (2014, May 12). Amandla! A Revolution in Four-Part Harmony [Video file]. Retrieved from https://www.youtube.com/watch?v=_UC5FlwPokY

Fountain, J.W. (2008, March 28). Soweto Freedom Song [Video file]. Retrieved from https://www. youtube.com/watch?v=8yrtK4K-GMg

This World Rocks. (2014, March 24). Toyi-toyi Protests during Apartheid in South Africa [Video file]. Retrieved from https://www.youtube.com/watch?v=wuQu0XleMGk

\section{West-Eastern Divan Orchestra, Middle East}

Carnegie Hall. (2012, January 25). An Introduction to the West-Eastern Divan Orchestra [Video file]. Retrieved from https://www.youtube.com/watch?v=K22pkacxfNo

Wall Street Journal. (2013, January 25). WSJ Live: Inside Barenboim's West-Eastern Divan Orchestra [Video file]. Retrieved from https://www.youtube.com/watch?v=CEEfjddzCPI 
The Telegraph. (2014, September 17). Daniel Barenboim interview: Why I'm proud of my orchestra [Video file]. Retrieved from http://www.telegraph.co.uk/culture/culturevideo/music video/11101112/Daniel-Barenboim-interview-Why-Im-proud-of-my-orchestra.html

Al Jeezera English. (2013, October 29). The Frost Interview - Daniel Barenboim: 'Spaces of dialogue' [Video file]. Retrieved from https://www.youtube.com/watch?v=VGRXCXSI9ao

\section{Cyprus}

tzevrou. (2015, May 11). The Bi-communal Choir for Peace in Cyprus sings at Voroklini [Video file]. Retrieved from https://www.youtube.com/watch?v=505isplh0l0

\section{Different Drums of Ireland}

sheeztrouble4u. (2009, September 24). Different Drums of Ireland performing Biddy McDole at Big Top Chautauqua [Video file]. Retrieved from https://www.youtube.com/ watch?v=ju4361FgvL0

Different Drums of Ireland (2006, September 9). Different Drums talk about their ethos and background [Video file]. Retrieved from https://www.youtube.com/watch?v=M0TIYTOm5Y8

TopOMornin2002. (2014, August 15). Different Drums of Ireland at 2014 Irish Fest [Video file]. Retrieved from https://www.youtube.com/watch?v=FFvSveQ7fSk

\section{Pontanima, Sarajevo}

Kurtz, S. (2013, March 23). Pontanima - Rachmaninoff's Bogorodice Djevo, Scenes of Sarajevo [Video file]. Retrieved from https://www.youtube.com/watch?v=1a98EsPajsU

Packham, A. (2011, July 12). Pontanima - Cuando El Rey Nimrod. Retrieved from https://www.youtube .com/watch?v=7|JX388U3Q4

\section{Cellist Vedran Smailović, Sarajevo}

Radio Free Europe/Radio Liberty. (2012, February 3). 20 Years after the Start of the Siege. A Return to Sarajevo [Video file]. Retrieved from https://www.youtube.com/ watch?v=HIJ7ICVW1SM

Bourqui, D. (2014, May 10). Cellist Vedran Samilovic playing Adagio by Albinoni [Video file]. Retrieved from https://www.youtube.com/watch?v=1HgZnd5KZCY

CanCult. (2009, April 2). The Cellist of Sarajevo by Steve Galloway [Video file]. Retrieved from https:// www.youtube.com/watch?v=2f7ZoYn_-A0

\section{Selected Films, Videos, and Music Embedded Within Text}

(In the order in which they appear in the text)

Carnegie Hall. (2012, July 30). Behind Bars: Music at Sing Sing [Video file]. Retrieved from https:// www.youtube.com/watch?v=TBYRMgPny-k

supportthefuture. (2012, April 13). Slave Spiritual Story - Wade in the Water [Video file]. Retrieved from https://www.youtube.com/watch?v=ZXqMQfpNSes

Bertelsen, M. (2008, January 24). Pete Seeger - We Shall Overcome [Video file]. Retrieved from https:// www.youtube.com/watch?v=QhnPVP23rzo 
Playing for Change. (2008, November 6). Stand by Me | Playing for Change | Song Around the World [Video file]. Retrieved from https://www.youtube.com/watch?v=Us-TVg40ExM

YouTube User 123. (2011, August 21). Song of Freedom (Estonia, Tallinn) Estonian Anthem and people singing all together [Video file]. Retrieved from https://www.youtube.com/ watch? $v=$ hqfBsSCmISc-

Festival International de Piano de La Roque d'Anthéron. (2014, July 1). West-Eastern Divan Orchestra - Daniel Barenboim - 13 août 2013 [Video file]. Retrieved from https://www.youtube. $\mathrm{com} /$ watch?v=3MRBOpRVoMg

Al Jeezera English. (2013, October 29). The Frost Interview - Daniel Barenboim: 'Spaces of dialogue' [Video file]. Retrieved from https://www.youtube.com/watch?v=VGRXCXSI9ao

London Review of Book. (2015, June 5). Daniel Barenboim's Edward W. Said Lecture, 2015 [Video file]. Retrieved from https://www.youtube.com/watch?v=srZOd4Uczo0

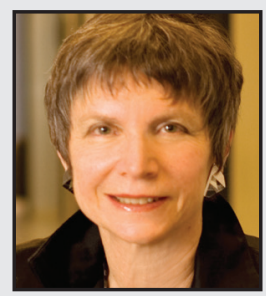

Nancy J. Adler is the S. Bronfman Chair in Management at McGill University. She conducts research and consults worldwide on global leadership, cross-cultural management, and artsinspired leadership practices. She has authored more than 125 articles, produced three films, and published 10 books and edited volumes. She is a Fellow of the Academy of Management, the Academy of International Business, and the Royal Society of Canada, and has been recognized as one of the top university teachers in Canada. Nancy is also a visual artist and has been an artist-in-residence at The Banff Centre. Her paintings and monotype prints are held in private collections worldwide.

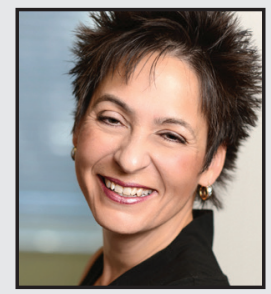

Linda Ippolito is a classical pianist, litigation lawyer, dispute resolution practitioner, teacher, and scholar. She studied music at Juilliard in New York City and University of Toronto's Faculty of Music, and law at York University's Osgoode Hall Law School. Linda has performed throughout North American and Europe as a soloist, vocal collaborator, and duo pianist. A senior partner at the law firm, Sheridan, Ippolito \& Associates, Linda also teaches at Queens Law School and Osgoode Hall Law School. Her research explores the intersection between music and conflict resolution. She has studied collaborative vocal musicmaking as an innovative approach to conflict resolution and peace-building as well as investigating the building of creative capacities through the use of music-based modalities. 